\title{
下咽頭部基底細胞癌症例
}

\author{
鎮西 邦彦 ・ 岸本 誠司 ・齋藤 春雄 \\ 甲藤 洋一.
}

\section{Basal Cell Carcinoma of the Hypopharynx; A Case Report}

\author{
Kunihiko Chinzei, Seiji Kishimoto, Haruo Saito, \\ Yoichi Katto, Yuji Ohtsuki and Hiroshi Sonobe \\ (Kochi Medical School)
} \begin{abstract}
literature.
The patient was a 64-year-old male with hoarseness. A fixed left vocal cord and a smooth large mass protruding to the false vocal cord and piriform sinus were found. A CT scan demonstrated a mass occupying the left glottic region and the piriform sinus. No lesion of the mucous membrane was detected by any clinical examination. A biopsy specimen showed probable basal cell carcinoma on ordinary histological and electron microscopic studies.

A small ulcer was found in the piriform sinus, which was considered to be the original focus of the tumor. Total laryngectomy with hypopharyngectomy and left radical neck dissection were performed.

Light microscopic, electron microscopic and immunohistological studies of the extirpated specimen confirmed the diagnosis of basal cell carcinoma.

The histopathology of basal cell carcinoma is discussed in some detail.
\end{abstract}

This is the first case report of basal cell carcinoma of the hypopharynx in the world

Key words: basal cell carcinoma, hypopharynx, histopathological diagnosis

はじめに

喉頭・下咽頭に発生する悪性腫瘍はほとんど が扁平上皮癌であり，基底細胞癌の報告はまだ ない，今回われわれは下咽頭化発生した基底細 胞癌症例を経験したので, 若干の考察を加え報 告する.

症例

患者：64歳，男性.

主訴：嗄声。
家族歴：特記すべきものなし.

既往歴：20年前, 局所麻酔下に喉頭ポリープ 摘出術施行 (病理組織像不明).

現病歴：1力月前よりの嗄声を主訴に来院.

現症：左仮声帯は表面平滑ながらも大きく腫 脹し，左声帯は固定していたが，左梨状陥凹の 狭小化は軽度であった。喉頭鏡・ファイバース コープによる観察にて粘膜病変は認めなかった. 右側喉頭亿異常はなく，両側頸部リンパ節の腫 
脹もみられなかった。

X 線検査：頸部 CT 撮影では，左声門上部か ら左声門部のレベルにかけて腫瘍陰影が見られ， 梨状陷凹の狭小化も見られた（図 1 ). その他, 胸部・消化管・シンチグラムなどの全身検索に て異常を認めず， $\mathrm{T}_{3} \mathrm{~N}_{0} \mathrm{M}_{0}$ Stage III の喉頭腫瘍 と考えられた。

第 1 回生検：間接喉頭鏡下に生検を行ったが, 採取された粘膜及び粘膜下組織には異常所見は みられなかった。

第 2 回生検 : 全身麻酔下に顕微鏡下の生検を

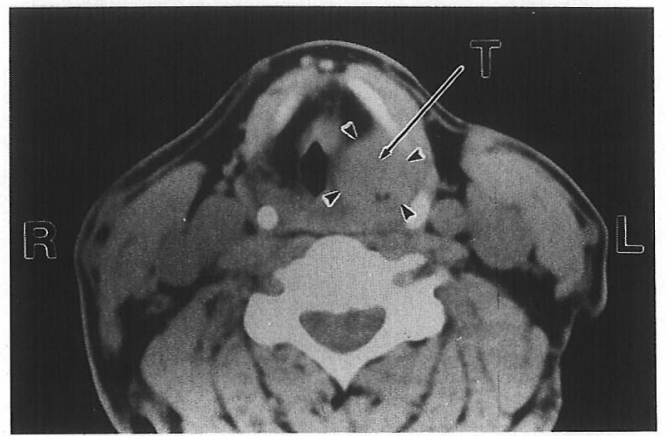

図 1 頸部 enhanced CT

均一に enhance された腫瘍陰影（T）を左声門から声 門上部にかけて認める。

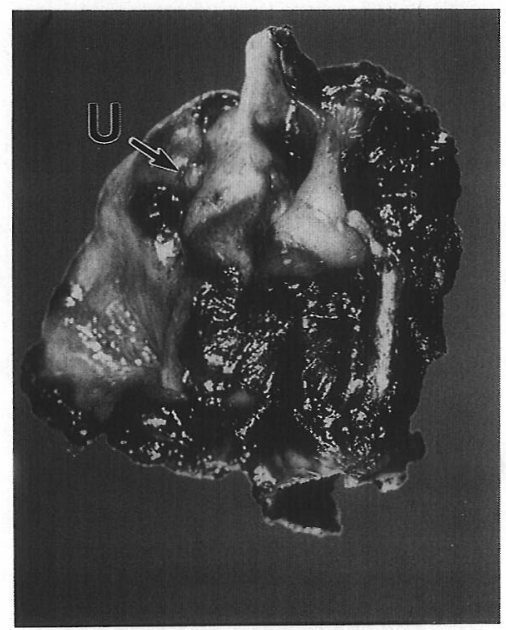

図 2 摘出標本 (後面)

左梨状陥凹部に小さな潰瘍病変（U）を認めた。他に は粘膜病変を認めなかった。
施行し，粘膜下深く检体を採取した. 光顕にて 基底細胞癌が疑われ，更に免疫組織学的・電顕 的に検討した結果，基底細胞癌と確定診断され た。

手術所見・摘出標本：喉頭摘出・左根治的頸 部郭清術を施行した。喉頭摘出時，左梨状陷凹 に小さな潰瘍病変がみられ（図 2 )，腫瘍はこ こ原発として，喉頭の声門上部に大きく広が っていたあのと考元られた。 このため同時に下 咽頭屯切除し，2 期的に食道形成を行った。腫 瘍の大きさは約 $5 \times 3 \times 2 \mathrm{~cm}$ で，声門部から声 門上部に広がっており，粘膜病変は，梨状陥凹 部にのみみられた。

病理組織学的所見 :

1）光顕；H.E. 染色では，絨細な間質を伴

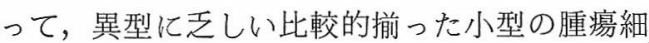
胞が， 1 〜層の規則的な椢状または束状構造 をとりながら胞巣を形成し，中心部壊死に陥っ たものもあり，これらは基底細胞癌あるいは力 ルチノイドを疑わす所見であった，腫瘍細胞の 核細胞質比は大きく，核小体は不明瞭ながら時 に認め，分裂像も散見した。胞巣部の一部に小 型の epithelial pearl の形成が少数ながらみら れ，腫瘍細胞の扁平上皮への分化を示していた. 軟骨・筋肉・脈管への浸潤やリンパ節転移は認 めず，明らかな皮膚付属器への分化も認めなか

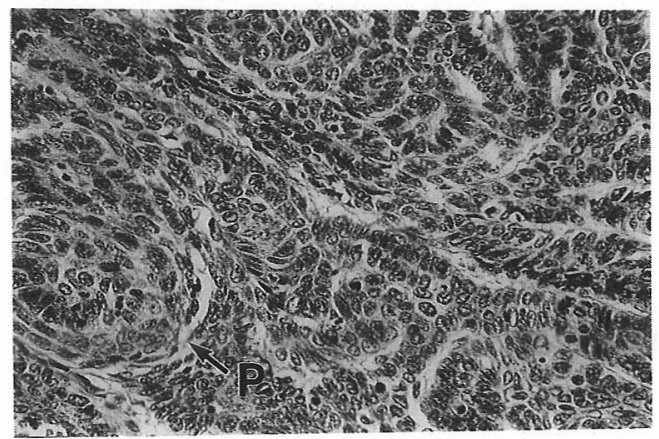

図 3 病理組織像 (光顕, $\mathrm{HE}$ 染色)

異型に乏しい比較的揃った小型の腫瘍細胞が， $1 〜 2$ 層の規則的な柵状構造をとりながら胞巣を形成して いる．腫瘍細胞の扁平上皮への分化を示す epithelial pearl $(\mathrm{P})$ 屯少数みられた。 
った（図 3)。また Grimelius 染色にて，陽性 顆粒がわずかに認められたが，分布・数・細胞 内での局在は通常のカルチノイド腫瘍の場合之 は異なっていた。

2) 免疫組織学的所見；ケラチン染色には 陽性であったが(図 4)，陽性部分は epithelial pearl 部に限局し，上皮性腫瘍の中でも分化度 の低いむのと考元られた. ほかに，EMA (Epithelial membrane antigen) 陰性, CEA 陰性であ り，いずれも基底細胞癌に矛盾しない結果であ

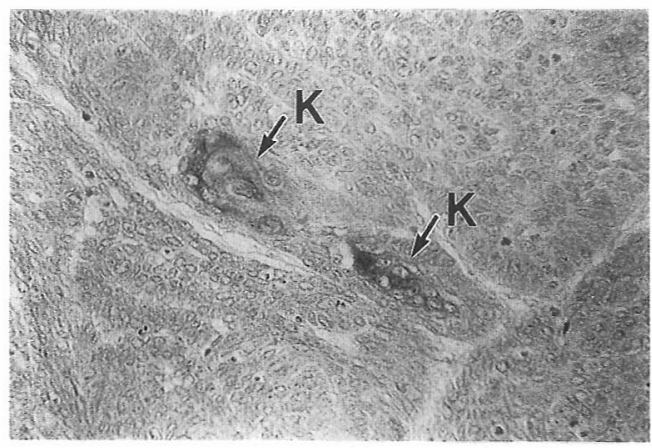

図 4 病理組織像（光顕, ケラチン染色）

ケラチン染色に陽性な部分（K）がごく一部に認めら れた。とのととは，腫痬が分化度の低い上皮性腫痬で あるととを示している。

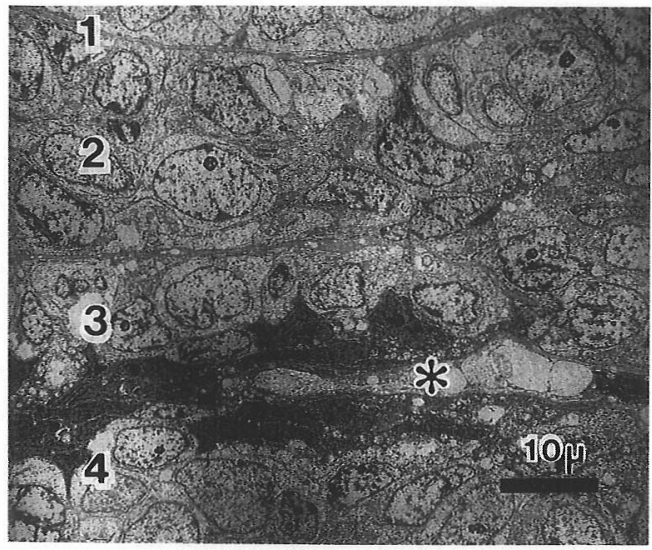

図 5 病理組織像 (電顕- I )

No. 1〜4の腫瘍細胞柵がみられる. 各細胞柵は基底 板によって個別に囲まれている，腫瘍細胞は細胞質に そしく，核の不整は軽度で，小型の核小体を有してい る.間質 (*) 近くには，より末分化な dark cells むみ られる。
った。

3）電顕；腫瘍細胞は柵状または束状に配列 し，基底板によって各細胞桐が個別に囲まれて おり，光顕での䒽状または束状配列に該当して いた，腫瘍細胞は，核の不整は軽度で，核質は 明るく，小型の核小体を有し，細胞質はそしか った (図 5 ). 更に強拡大で 観察すると, 接着 斑の形成と張原繊維の存在はごく一部で顕著で あり，乙の腫瘍の扁平上皮的性格がうかがわれ た（図6）が，乙のような部分は全体に少なく， 分化度の低い腫痬であると考えられた．また腺 腔形成は認められず，分泌顆粒む認めなかった。

以上の光顕, 免疫組織学的, 電顕的検討によ り, カルチノイドは否定され, 腫瘍は扁平上皮 への分化傾向を一部で示す，基底細胞癌である と診断した。

術後経過: 術後 2 年を経過した現在, 再発を 認めず健在である。

\section{考按}

喉頭・下咽頭に原発する悪性腫瘍は扁平上皮 癌が大部分を占めており ${ }^{122}$ ， 内外文献を渉猟 した範囲内では，基底細胞癌の報告はない，

本症例を基底細胞癌と搒断した病理学的根 拠について述べる。.まず光顕的には，比較的

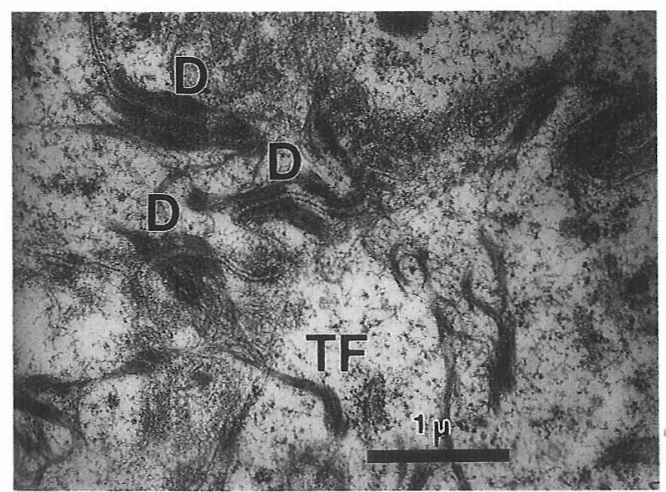

図 6 病理組織像 (電顕- П, 強拡大)

部分的には, 著明な接着斑の形成 (D), 著しい張原 繊維の発達 $(\mathrm{TF})$ を認める. 
均一な腫瘍細胞の柵状配列が見られ，epithelial pearl 形成のような腫瘍細胞の扁平上皮への分 化が一部に見られる．乙のような一部での扁平 上皮への分化は，ケラチン染色による陽性部分 が少ないことからもいえる. 免疫組織学的に，

EMA 染色は, 多くの腺癌, 角化扁平上皮癌 で陽性，他の腫瘍組織型では陰性であり，CEA 染色は，扁平上皮癌や多くの腺癌で陽性である のに対し，基底細胞癌では陰性である37. 本症 例では, EMA・CEA 共に陰性であり, 基底細 胞癌に矛盾しない。電顕的にも各腫瘍細胞䒽が 基底板により個別に区切られ，各腫瘍細胞には 部分的には強いが全体としては接着斑の形成と 張原繊維には乏しく, 增殖腫瘍細胞の基底細胞 的性格をあらわしている，ただ一般に，基底細 胞癌は扁平上皮的性格を有するため時に扁平上 皮癌との鑑別が困難なととがあり，その際電顕 は余り有用でない( ${ }^{4)}$. 本症例で屯最終的に基底 細胞癌と診断したのは，扁平上皮への分化傾向 を示す腫瘍細胞が，光顕でみられるような特異 的な柵状配列を示したためである。ただ典型的 な基底細胞癌では, 柵状配列が癌胞巣の主に辺 縁側で見られるのが普通であり ${ }^{5)}$ ，本症例は基 底細胞癌の中でも特殊型と考えられる，その点 を考えると，腫瘍の本質はむしろ分化度の低い 扁平上皮癌に近いと考えることもできる。

Wain $ら^{6)}$ は舌, 下咽頭, 喉頭癌の計 10 例に つき，上皮基底細胞に類似した basaloid component と扁平上皮癌成分とを併せもつものと して “basaloid-squamous carcinoma” という概 念を提唱している. 即ち basaloid 性格として, 細胞質に之しくクロマチンに富み核小体を有し ない小型の暗調腫瘍細胞が充実性に增殖し，一 部中心部壊死に陥ったものとし，扁平上皮性格 としては，個々の細胞のケラチン産生，細胞間 橋，ケラチン角化巣，モザイク配列などを挙げ ている．本症例もこの概念に近いと言える，た だこの10例のうち 1 例を除いて，隣接部位に扁 平上皮癌を合併しており，本症例とはこの点で 異なるとと，更にての疾病概念がはっきりとし
た病理組織学的概念として確立されたものでは ない点之, 本例での扁平上皮への分化傾向がご く軽微である点などを考慮して，本症例を基底 細胞癌と診断した。

本症例の発生部位は下咽頭としたが，声門上 部癌之梨状陥凹癌とは，部位的に極めて近接 しているため，鑑別診断に難渋する場合があ ある7). 本症例では潰瘍病変の見られた下咽頭 原発の癌之診断したが，いずれにせよ基底細胞 癌の発生部位としては特異である。基底細胞癌 は，主として皮膚に，特に胎生期の顔裂線に一 致して顔面に多く発生することの多い腫瘍であ り，粘膜での発生はきわめて稀である ${ }^{8)}$. 粘膜 での発生例として食道腫瘍がある。68施設の集 計を行った Suzuki と Nagayo" 科切除された 11,783 例の食道覀性腫瘍中, 扁平 上皮癌は $97.83 \%$ と大部分を占め，基底細胞癌 屯 8 例 $0.07 \%$ にみられる. この 8 例中 5 年以上 生存したものはなく，乙の癌の悪性度の高さが 筧われるが，症例数屯少なくはっきりとした予 後は明言できない。一方皮膚の基底細胞癌では, 局所での侵襲性は強いものの転移は稀であり， 予後は良好である ${ }^{51}$. 本症例の予後はいずれに 近いのか，治療を考えるときに重要である.

基底細胞癌の発生誘因としては，他の皮膚癌 之同様に日光, 紫外線, 放射線, 外傷, 熱傷, タールなどある種の化学物質, 慢性炎症などへ の持続的暴露が考えられている ${ }^{5)}$. しかし本症 例ではこの様な既往歴はなく，皮膚癌の家族歷 む，また熱い飲物や強い酒の嗜好むなかった。 ただ一日30本の喫煙歴と喉頭ポリープ摘出術の 既往があるだけであった，つまり病因論的に基 底細胞癌の発生を支持するものは特にないと云 うととになる。また他の部位からの基底細胞癌 の転移と云うととも，全身検索にて異常を認め ず，考えにくい.

基底細胞癌の治療の第一選択はまず外科切除 であり，その他敒射線療法，凍結療法，局所 化学療法などが使い分けられ，95\%の治療率で あるといわれる $3^{510)}$. 本症例では外科切除のみ 
を行い，放射線治療は行なわなかった，それは この高い治癒率と, 放射線が基底細胞癌の転移 能を高めるという考えのあるとと ${ }^{11}$ ，更に周囲 組織への浸潤が全くなく非常におとなしい癌腫 と考えたためである. 今後の経過観察により下 咽頭に発生した本症例の基底細胞癌が，皮膚に 発生するあのに近い性格を持つものか，食道に 発生するものに近いものか，腫瘍の真の性格が 明らかになっていくものと思われる.

\section{結語}

64歳男性の下咽頭基底細胞癌の一例を経験し た。下咽頭に発生した基底細胞癌の報告は文献 上本例が最初である. 病理学的検索により, 本 症例の基底細胞癌は分化度の低い扁平上皮癌に 近いが，ごく一部に明らかな扁平上皮への分化 を認めるのみであり，基底細胞癌としての妥当 性について考察を加えた。

稿を終えるに臨み，病理学的検索にご協力いただい た当大学附属病院中央検査部病理の森木利明博士に感 謝の意を表します。

尚, 本論文の要旨は第 14 回日本耳鼻咽喉科学会中 国・四国地方部会連合学会（昭和63年12月 2,3 日, 米子)にてロ演した.

\section{参考文献}

1) Ferlito A : Histological classification of larynx and hypopharynx cancers and their clinical implications. Acta Otolaryngol Suppl 342 : 15 27, 1976.

2 ）佐藤武男：喉頭癌一その基礎と臨床一．115～122 頁，金原出版，東京，1986.

3 ）斎藤 脩, 水口國雄 : 免疫病理診断法一基礎と実 際一. 279 291 頁, 医学書院サウンダース, 東 京, 1987.
4) Henderson DW, Papadimitriou JM and Coleman M : Ultrastructural appearances of tumors. Diagnosis and classification of human neoplasia by electron microscopy. pp 75 76, Churchill Livingstone, New York, 1986.

5 ) Domonkos AN, Arnold HL and Odom RB : Andrews, diseases of the skin. Clinical dermatology. pp 810 822, WB Saunders Company, Philadelphia, 1982.

6) Wain SL, Kier R, Vollmer RT, et al : Basaloidsquamous carcinoma of the tongue, hypopharynx, and larynx; report of 10 cases. Hum Pathol $17:$ 1158 1166, 1986.

7 ）宮原 裕, 馬谷克則, 吉野邦俊, 他：喉頭癌と下 咽頭癌境界症例の臨床的検討. 癌の臨 $30: 1401$ 〜1406, 1984.

8) Ono $\mathrm{T}$, Kitoh $\mathrm{M}$ and Kuriya $\mathrm{N}$ : Characterization of basal cell epithelioma in the Japanese. J Dermatol $9: 291 \sim 300,1982$.

9 ) Suzuki $H$ and Nagayo $T$ : Primary tumors of the esophagus other than squamous cell carcinoma; histologic classification and statistics in the surgical and autopsied materials in Japan. Int Adv Surg Oncol 3 : 73 109, 1980.

10) Moschella SL, Pillsbury DM and Hurley HJ : Dermatology (vol 2). pp 1351 1354, WB Saunders Company, Philadelphia, 1975.

11) Conley J, Sachs ME, Romo T, et al : Metastatic basal cell carcinoma of the head and neck. Otolaryngol Head Neck Surg 93 : 78 85, 1985.

(原稿受付 : 平成元年 7 月 3 日

原稿採択 : 平成元年 7 月 20 日 別刷請求先：鎮西邦彦

干781-51 南国市岡豊町小蓮 高知医科大学耳鼻咽喉科学教室） 